\title{
The Expression of "Enak" (Delicious) for Food in Social Media Instagram
}

\author{
${ }^{1 *}$ Khusnul Khatimah, ${ }^{2}$ Rawinda Fitrotul Mualafina, ${ }^{3}$ Cut Irna Liyana \\ 1*STKIP Taman Siswa Bima, Indonesia, khatimah19@gmail.com \\ ${ }^{2}$ Universitas PGRI Semarang, Indonesia, rara.fina@gmail.com \\ ${ }^{3}$ Universitas Teuku Umar Aceh, Indonesia, cutirnaliyana@utu.ac.id
}

Submitted: 10/09/2021 Revised: 20/10/2021 Accepted: 14/11/2021

How to cite this article: Khatimah, K., Mualafina, RF., \& Liyana, CI. (2021). The expression of "Enak" (delicious) for food in social media Instagram. International Journal of Education, Language and Religion. 3(2), 65-73. doi: 10.35308/ijelr.v3i2.4511

\begin{abstract}
The purpose of this study is to describe the form of expressions "enak" (delicious) in Instagram social media and the function of using these forms. The method used is a descriptive qualitative method with data collection techniques in the form uninvolved conversation observation technique on the use of expressions "enak" on several Instagram accounts. The results obtained are (a) the form of "enak" expressions is in the form of standard expressions, religious sentences, prefixes ter- and se- in the form of slang, and hyperbolic expressions; (b) the function of using this form is to promote food products, create a contemporary impression, and provide a more concrete picture.
\end{abstract}

\section{Keywords}

Delicious expressions; food; Instagram; slang; sociolinguistics

\section{Introduction}

As a part of society, language plays an important role, one of which is in providing convenience for speakers to express themselves. With language, a person can express his admiration not only with facial expressions and gestures, but also verbally with more diverse forms so that the expression will be conveyed better (James, et.al., 1998; Goel, A., Rugaber, S., \& Vattam, S.,2009; Lorenz, 1953). In this regard, Holmes (1992:2) states that in addition to acting as a means of conveying information, language can also act as a means of conveying the feelings felt by a speaker.

The role of language as a means of expression cannot be separated from the diversity of its features, situations, and means of use (Roberson, D., Damjanovic, L., \& Kikutani, M.,2010; DeAndrea, D. C., et. Al., 2010). In the sense that as something dynamic, this language, especially in relation to the speaker's means of expression, will not be present in the same form continuously. Directly or indirectly, the diversity of speakers, in terms of age, gender, ethnicity, and also social strata, including the means of use, both oral and written, greatly influences the form of expressive expressions. When the age of the speaker who expresses it is a teenager, not necessarily the form shown will be the same as when the speaker's age is 10 years older. Likewise, when the situation and means of use are different, of course this expression will also be present in different forms. 
One form of expression that is unique and interesting to observe is the expression of a speaker when expressing the word delicious to food in various forms. Phrases such as delicious, very delicious, very tasty, are a number of expressions that are often used to express the taste of food. Along with the development of the times, including the means of using language, it turns out that the form of expressive expressions of food also develops. One of these phenomena is found in the use of language on social media. As a means of using language, social media not only shows the use of new, but also unique languages that have forms that are rarely used in other media. Instagram social media, for example, shows the use of distinctive language, including the use of expressions, especially for food. Based on a simple survey that has been carried out on Instagram social media, it is found that the forms of expressing words delicious are distinctive. For example, the use of the following sentences:

(1) Recomended banget ini rasanya enak banget, sumpah mau nangis

'Highly recommended, this tastes really good, I swear I want to cry'

(2) Gilaaa siii ini enak banget, pedesnya nampol, rasanya kek mau meninggal

'This is crazy, it's really delicious, it's spicy, it tastes like I'm going to die'

If you pay attention, the two expressions conveyed through Instagram social media are not just the words delicious or very delicious. The expressions conveyed are present in other, longer and unique forms that can be seen in the use of words swear, want to cry, crazy, nampol (being slapped), want to die. Explicitly, of course, these forms show extreme expressions to state that the food they eat is very good. In addition, it can be seen implicitly that today's netizens no longer feel enough to use common words in expressing their expression of the taste of food. It is as if the form of the word is superlative with the words sangat, banget, sekali, bukan main (expressing feeling of "very or really"), no longer enough to express his feelings for the sensation he receives. As such, they tend to create new, different forms that often have a hyperbolic feel.

The factor that was later found to be related to the use of such forms was none other than the indirect nature of the use of language in social media, both shown through writing and photos; make the communication becomes indirect as well. Thus, it is necessary to have a means to make communication through written language that can make it more real so that the reader of the writing seems to be able to feel the pleasure earlier. This is in line with an article written by Mualafina (2017) which states that as a means of using language, social media presents a form of language and the use of certain symbols with one goal, namely to make indirect written communication feel more real.

Through this simple article, we will discuss a number of expressions delicious for food used in Instagram social media, including the function of using these forms of expression. As previously stated, these forms of expression cannot be separated from the fact that language cannot be separated from its people, especially when it comes to its users and means of using them.

A number of previous studies with the object of language studies in social media have been conducted. Sari (2016), in an article entitled "Variety of Alay Language in Social Networks", shows that the form of language used in social networks is a form of Alay language that has undergone changes in form, both in terms of phonology and morphology.

The article entitled "Using Asterisk (*) in Social Media" written by Mualafina (2017) also uses social media as an object of study. This article discusses the use of asterisks in social media. The result that is then obtained is that the use of asterisks in social media no longer follows the initial rules for the appearance of the sign or symbol. Its use has developed into a means, one of which is to liven up the atmosphere of using language through social media so that it feels more real.

Regarding the use of language on Instagram, Rahmasari (2018) once wrote a thesis with the object of study in the form of various languages on Instagram social media and its contribution to teaching Indonesian in high school. In her thesis entitled "Characteristics of Language Variety in Instagram Social 
Media and Its Contribution to Indonesian Language Teaching in Senior High Schools", Rahmasari explained that the language used in this social media is unique, among which is conveyed through word abbreviations, writing words and phrases that are different from the original form. origin, as well as the use of symbols and numbers as well as the presence of greetings and switching and code mixing.

Furthermore, Wijayanti and Shalima (2018) have also reviewed the use of language in Instagram social media, especially regarding the forms of homonyms and polysemy in an article entitled "Homonimi and Polysemy in Instagram Funny Uploads". In this article, it is mentioned that there is a use of language style; the use of names or titles, abbreviations, and the divergence of meaning in the formation of homonyms. In addition, there is also a shift in meaning, use of terms, and metaphors in the formation of polysemy.

In addition, Indrasari et al. (2019) also wrote the pattern of language use on Instagram social media in an article with the title "Netizen Sarcasm Language in Comments on the Instagram Account 'Lambe Turah'. It is explained that in the comments of the account, there are many violations of the principle of politeness in language with a number of background factors, including showing self-existence and selfexpression.

\section{Method}

The method used in this study is a qualitative descriptive method. Data collection was carried out through uninvolved conversation observation technique and involved conversation observation technique. Involved conversation observation technique is used for collecting some data which is indeed used by the researcher, while the uninvolved conversation observation technique is used to collect other data taken from the use of the language of the other party. The collection was continued with the technique of noting on the data card to facilitate the classification and analysis process. In this case, the data source is Instagram social media, especially those containing content that shows the use of expressions for food. After the data is collected, a descriptive analysis is carried out which is then presented informally in words.

\section{Results and Discussions}

Based on the data that has been collected, it is found that there are two things that become the data in this paper, namely the form of expressions delicious and the function of using these forms in Instagram social media.

\section{Forms of Expressions Delicious}

In the previous explanation, it was written that expressions delicious of food on Instagram social media come in a unique form that has a certain pattern. When the same form is then used in other language use domains, the source of its use still comes from the use of language in social media, especially Instagram. A number of these forms will be described one by one as follows, some of which are present in the form of standard expressions, in the form of slang, the use of religious interjections, the use of foreign languages, puns, and hyperbolic expressions.

\section{a. Standard Forms of Expression}

Among the many unique uses of language, especially in the case of expressions delicious for food, it is not uncommon for these expressions to be present in standard forms that are commonly used by the community. The standard expression referred to in this case is the use of adjectives related to the sense of taste, such as delicious and tasty, complete with reinforcement words, such as very, really, and pol in Javanese. Some of the data found in this category include:
1) mantap pol
3) sangat enak
2) enak banget 


\section{b. Religious Sentences Religious}

Sentences are also found in the context of writing delicious expression for food on social media. In this case, what are often found are sentences in the Islamic religion, such as subhanallah, masyaaAllaah, alhamdulillaah, and ya Allah. The four of them are often found accompanying delicious expressions written by netizens in expressing the delicious taste of the food they enjoy. A number of data in this form include:

4) masyaa Allaah enak kali 'masyaa Allah it is very delicious'

5) subhanallah enak banget 'subhanallah it is very good'

6) aduh, ya, Allaah, aku ga sanggup kalo lihat begini, lemah akutu 'oh, yes, Allah, I can't stand to see it like this, I am weak'

7) seenak ini, ya Allaah 'this is delicious, $O$ Allah'

8) alhamdulillaah cucok di lidah 'alhamdulillaah it fits on the tongue'

In addition to using the four religious sentences above, the expression delicious is also accompanied by a verse from the holy kibat, namely the Qur'an which is generally used to express the many blessings of God that have been received, as shown below.

9) fabiayyiaalaairabbikumaatukadzibaan

\section{c. Affixes ter- and se-}

Standard rules of grammar In Indonesian, affixes ter- commonly used in passive verb meaning involuntary and superlative meaning most or very. The meaning of the suffix se- is the same, commensurate, and similar. In the collected delicious words in Instagram social media, the two affixes were found to be used. Some data show the usage that is in accordance with the rules, some other data shows usage that deviates slightly from the existing rules. One of these usage deviations is seen in the attachment of the affix to a certain word which actually has no grammatical meaning and rules. Some data with the affixe ter-and se-in the delicious expression is as follows.
1) Gak kuadd terenak
2) Camilan terdahsyat
3) Terngidam
4) Terlagi-lagi
5) Terlove
6) Ini paha ayam terendes saentero! Teristimewa!

7) Seenak itu

8) Selembut itu lho cake-nya

9) Sumpah brownisnya enak. Seenak, sepadat, dan selembut ini. Puas kaliii 'I sure the brownisnya is tasty. As delicious, as dense, and as soft as this. Satisfied'

10) Selezesss itu

As shown in the ten data, the affix ter and se-is used in the expression of delicious food. On the data (10) - (14) affixes used is ter-, that is terenak, terdahsyat, terngidam, terlagi again, and terlove. The five are used to express how the food enjoyed is food with a very good taste that even beats the taste of other similar foods.

If you notice, sticking affix ter- to these data do not entirely follow the rules set out in the use of prefixes in Indonesian. There is a language game as a form of slang in the realm of social media. This is especially evident in the data (11) - (14). In data (11), there is the word terdahsyat. According to the Big Indonesian Dictionary, the word dahsyat is defined as 'terrible, scary, great, very very'. When viewed from this meaning, its use in expressing the taste of food is inappropriate. Not to mention the added adhesion ter- to words dahsyat that infringe the grammatical rules of affixation in Indonesian. This is certainly form of using slang a uniquein the realm of language use on social media, especially Instagram. So it can be said that the use of the word "dahsyat" in the "terdahsyat" is an illustration of how incredibly delicious the food that is being discussed is. 
The same thing also happened to data (12), namely the word terngidam. The word is formed from the process of affixation prefix ter- of the word ngidam that in the Indonesian language written with the idam. In the rule, affixes ter-attached to the adjectives to get the superlative meaning and the verb for the meaning "unintentionally". When viewed from the context of its use, the form of terngidam is not included in both. This form is merely a language game that simply attaches the form of affixes to words that are not in accordance with the category of words that can be attached to the affix in question, namely ter-.

Cases that are not much different also occur in data (13), namely terlagi-lagi. Terlagi-lagi is a form of affixation rules that is not grammatically correct. The basic form terlagi-lagi is from the base lagi that is reduplicated in adverbial category. This form generally used in the context of an informal conversation with the meaning of repeating something several times. When then the base is attached to the affix terwith a superlative meaning and for sure terlagi is not a grammatical form in Indonesian. This form is generally used to mean that something that is enjoyed, in this case in the form of food, is something that invites the appetite to always eat it again and again or repeatedly because it tastes very good.

Data (14) is somewhat different from the previous data. Affixes ter-attached to the word love which is the vocabulary of the English language. In Indonesian, there is indeed a form of beloved when the word "love" is translated directly. However, if you look at its conformity with the rules, of course this form is not acceptable because there are no rules that allow affixes in Indonesian to be attached to words from foreign languages, as shown in the form terlove in the data (14). In its use, this word is used to show the superlative meaning of the delicious expression that the food enjoyed is the most preferred food because it tastes very good.

The other attachment of afiixe ter-also looked at the data (15). The words in this data are somewhat different from the previous data. In this data (15) there is the word terendes which is formed from the affix ter with the word endes, a form slang of the word enak. This word is of course the result of a language game which is then used to express delicious expressions in food by including the affix terwith the intention that the food enjoyed is the most delicious.

If some of the previous data involved the use of the suffix ter-, data (16) - (19) involved the use of the suffix se-. In the rule, se- is used to express the meaning of the 'same' and 'one'. In the Big Indonesian Dictionary, this affix is even mentioned as an affix to form an adverb. If you look at the fourth data, the meaning of $s e$ - is 'the same, equivalent'. What is then different is the form of attachment of the affix, the word which is then produced, including the context of the use of the word which has undergone a slight expansion. The data (16) - (18) show that invented words are normally used by public, namely seenak (as delicious as), selembut (as soft as), and sepadat (as dense as). Somewhat different from the three previous data, affix se- the data (19) are attached to slang word lezat, namely lezes become selezes are generally used in the context of conversation and informal use of language. Of course, this form again shows the existence of a language game in expressing delicious food on social media, especially Instagram, as discussed in the next subchapter.

\section{d. Forms of Slang}

Slang is known as a form of language that is used socially in certain domains by a language community. This slang is often present in the form of language games in the form of the use of words that are transferred from the realm of their use to other domains or the word form is transferred to a more unique and distinctive form. A number of delicious expressions on food that are used by netizens on Instagram show the symptoms of this kind of language. From the data collected, it is found that there are many forms of expressions that are part of this slang. Some of the data found in this form are as follows.
1) tasty bingitzz.
3) nak nget
2) nak nan
4) endolita 

5) endul beud
6) lezatoz
7) selezessss itu
8) maknyus nyus nyus nyusss

9) Edun

10) terlagi again

11) terngidam

12) enak banget sampe mau meninggoy

Data (10) - (22) is an expression of delicious that comes inform of slang, as previously mentioned. Data (10) - (12) contains the expression form of the word delicious. The word is then added and changed into another, more unique form. Data (1), for example, to add the word bingitzz which is a form slang of the word sangat (very). The data is somewhat different from data (11) and (12), in both data, the word delicious is changed to a short form by removing the first syllable, namely $e$ leaving the second syllable nan followed by other forms slang. In data (11), the form of nak is followed by the form of nget which is derived from the second syllable of the word banget. Similarly, data (12) that the word nak is followed by the second syllable of the "very" word. In this case, the "very" word comes from the Javanese language, namely tenan becomes nan so that it forms the expression nak nan which means 'very tasty'.

Furthermore, language games that become slang also seen in data (13) and (14). Both of these data actually use the basic word enak, as the three previous data. However, the form has been changed to be more unique. In data (13), the word enak is changed to endulita, while in data (14), the word enak is changed to endul and followed by the word beud which comes from the word banget (very/ really).

The uniqueness of the expression form is also seen in data (15) and (16) which are derived from the word lezat (delicious). In data (15), it comes from the word lezat which is changed to the word lezatos. Slightly different from data (15), data (16) is formed from the expression as selezat itu (as delicious as that) which is changed to selezesss. In its use, this expression is followed by another expression in the form of a crying emoticon by using an asterisk sign as an expansion of the situation (Mualafina, 2017).

Data (17) shows a different slang, namely maknyus nyus nyus nyusss. This expression was very popular in the early 2000s which was introduced by a culinary presenter, Pak Bondan. Since then, the word maknyus has been associated closely with the expression of delicious for food. Not only used orally, but also in writing, especially on social media, such as Instagram.

The other uniqueness of slang expressions can be seen in data (18) in the form of the word edun. This word comes from the word crazy which is used to express how good food tastes. Another uniqueness is also found in the data (19) and (20). In these two data, there is the formation of delicious words in the form of sticking the affix ter-, as will be explained in the next subsection. The uniqueness of this form is seen from the attachment of a word with a passive affix ter-which is actually not grammatically correct, namely the word terlagi-lagi and terngidam.

Data (21) is formed from words that are not even related to the sense of taste, which will be discussed further in the next subchapter. The word is meninggoy which comes from the word meninggal (died). This word is often found in the context of delicious expressions in the form of sentences to express how delicious food is, so that even the superlative words in the language do not adequately describe the delicious taste. In addition, the word seems to be used to express that the food taster has achieved the highest pleasure in his life.

\section{e. Hyperbolic Expression}

A number of data indicate the use of words that are not even related to the sense of taste. There is a kind of synesthesia or transfer of sensory function in the expressions found, as shown in the following data.

22) Camilan terdahsyat. 'The worst snack'

23) Ini paha ayam terendes seantero! Terisitimewa. 'It's thigh the coolest chicken all over! Special'

24) Kuenya super duper enak. 'The cake is super-duper delicious' 
25) Recommended banget ini. Rasanya enak banget sumpah mau nangis. 'This is really recommended. It tastes so good I swear I want to cry'

26) Gila sih enak banget pedes nampol, rasanya kek mau meninggal. 'It's crazy how delicious it is spicy nampol, it feels like I'm going to die'

27) Sumpah brownisnya enak. Seenak, sepadat, dan selembut ini. Puas kaliiii. 'I swear the brownies are delicious. As delicious, as dense, and as soft as this. Satisfied, I swear'

28) Sumpah aku jatuh cinta sama kejunya. 'I swear I fell in love with the cheese'

29) Sumpah demi apa ini parah enaknya. 'I swear by what this is so bad'

30) Ya Allaah kenapa ini harus terjadi. Kenapa harus cobain donat inih. Jadi kecanduan deh. Terlalu surge. 'Oh Allah why did this have to happen. Why should you try this donut? So addicted. Too surge.'

31) Ya Allaah ini surganya donat. Rotinya lembut kayak sutra. 'Oh Allah, this is donut paradise. The bread is soft like silk'

32) Aduh ya Allaah ya Allaah... aku ga sanggup kali lihat begini, lemah akutuh. 'Oh my God, my God... I can't stand to see this, I'm so weak'

33) OMG, Kak, ini dibuat dari apa sih? Enak banget ga bisa berkata-kata. 'OMG, Sis, what is this made of? It's so good that I can't even speak'

34) Ga ikhas coklatnya tinggal di tempatnya. 'I don't know where the chocolate is actually'

35) Gaenak. Rugi beli. Maksudnya rugi beli satu. Ga enak ga puas. 'It's not delicious. Buying loss. It means a loss buying one. Not good not satisfied'

The thirteen data that have been mentioned are data that contain hyperbolic expressions related to the expression of delicious food. The thirteenth is included in this category because the form of expression used is formed from words and sentences that seem to exaggerate the actual portion. In other words, the formation of this hyperbolic delicious expression occurs, both from the diction used to the sentence structure. In data (25) and (26), for example, there is the use of the words crying and dying. These two expressions are very often found in delicious phrases on Instagram when speakers want to express that what is being praised is a very delicious food and is something that is at the peak of pleasure that has been felt. It was so delicious that even superlative adjectives couldn't describe the feeling.

Hyperbolic expression is also done by including taka oath in the speech used, as shown in data (28) and (29). The word oath is generally used to express the sincerity of something important, for example in statements, agreements, even wrong and right decisions. When it is then used in the context of a delicious expression of food, of course the use of the word oath becomes redundant.

The hyperbole form also appears in the next speech data, namely (30)-(35). The hyperbolism of speech in the six sentences is due to the arrangement of the sentences used. Data (30) and (31), for example, contain the use of a metaphor by comparing the taste of donuts with the pleasures of heaven and the softness of silk. The comparison was made to provide a more real picture of the quality of the taste of the donuts he ate. Things that are not much different are also seen in the data (31) and (33) that speakers cannot express the deliciousness of the food they enjoy because the food is very tasty. It is stated in it that it is as if the food enjoyed makes the speaker helpless and unable to speak.

For the last two data, namely data (34) and (35), the hyperbolic side is indicated by the use of rejection and negation expressions. The expression seems to express a rejection of the quality of the taste of a food, but in the end the expression is meant to show how good the food is. Use of phrases gak ikhlas (not Iklhas) and gak enak (not good) to repression expression conveyed that the speaker was not sincere and loss when he was just enjoying the food at all. In other words, he wants to express that the food in question must be bought and eaten again and again because it tastes very good. 


\section{Functions of Using Phrases Delicious}

After describing a number of expressions delicious for food in the previous discussion, it appears that the use of these forms is not done without reason. These reasons are summarized in the function of using these forms of expressions, especially in the use of language on Instagram social media. Some of the functions in question are as follows.

\section{a. Promotion of Food Products}

Persuasive sentences are understood as sentences used to invite and suggest something to others. From the acquisition of existing data, most of it is devoted to the promotion of a food product. This promotion is not only limited to netizens who are indeed endorsed by the product owner, but also those who voluntarily promote a food with a good taste. A number of data that carry this function are as follows.

1) Recommended banget ini. Rasanya enak banget sumpah mau nangis. 'Recommended This is really. It feels really good I swear I want to cry'

2) Gila sih enak banget pedes nampol, rasanya kek mau meninggal 'It's crazy how delicious it is spicy, it feels like I'm going to die'

3) Selezessss itu *emot menangis. 'It's delicious *cries crying'

4) Sumpah brownisnya enak. Seenak, sepadat, dan selembut ini. Puas kaliii. 'I swear the brownies are delicious. As delicious, as dense, and as soft as this. So satisfied'

\section{b. Creating a Contemporary Impression}

As part of something dynamic, language is not fixed. That is, the form of language used at a time describes the current phenomenon that occurred at that time. This is evident in the expression of delicious food on Instagram social media. Some data show that diction and word formation in existing expressions are forms of language that are being widely used by netizens, especially in social media Instagram, as shown in the following data.

1) endul beud

2) Selezesss it * emot cry

3) Terlagi-lagi

4) awful until want meninggoy

5) Recommended this buildup. It feels so good I swear I want to cry

These data contain contemporary language or slang which is currently being widely used in Instagram social media. The peculiarities that appear include the use of slang, affixes ter- and se- which even produce invented words that are not grammatical, including the use of hyperbolic expressions which are widely used in expressions of feelings that show extremeness.

\section{c. Providing a more concrete picture}

Apart from being a form of contemporary language in social media, the expression of delicious food is also present to liven up the atmosphere of speech. This function mainly arises from a number of data generated from language games and hyperbolic expressions. The use of this kind of expression is mainly done to provide a more concrete picture to the reader of the feeling that is being described. A number of data containing this function are as follows.

1) Selezesss *cries in tears

2) Camilan terdahsyat. 'The best snack'

3) OMG, Kak, ini dibuat dari apa sih? Enak banget ga bisa berkata-kata. 'OMG, Sis, what is this made of? It's so good to be speechless'

4) Ya Allaah ini surganya donat. Rotinya lembut kayak sutra. 'Oh Allah, this is donut paradise. The bread is soft like silk'

5) Ya Allaah kenapa ini harus terjadi. Kenapa harus cobain donat inih. Jadi kecanduan deh. Terlalu surge. 'Oh Allah why did this have to happen. Why should you try this donut? So addicted. Too heaven' 
6) Sumpah brownisnya enak. Seenak, sepadat, dan selembut ini. Puas kaliiii. 'I swear the brownies are delicious. As delicious, as dense, and as soft as this. Satisfied.'

Through a number of these expressions, the reader will indirectly imagine the delicious taste that is expressed; even then it is likely that the reader who is reading swallows saliva because he imagines the food being discussed. Furthermore, when the taste is already imagined, the reader will be moved to order the same food to feel the sensation of delicious taste that has been read and imagined by him from the writing of the delicious phrases he reads. The use of the words sepadat (as dense as), selezez (as delicious as), terlalu surge (too heaven), kayak sutra (like silk), gak bisa berkata-kata (speechless) are a number of parts of delicious expressions that contain the function of providing a more concrete picture to the reader.

\section{Conclusion}

As part of the medium of language use, Instagram has many language phenomena that can be observed, one of which is the use of delicious expressions for food. Based on the observations and analyzes that have been carried out, it can be concluded that the expressions used to express good taste are present in a distinctive form. This peculiarity appears not only from the sentences that are composed, but specifically from the diction and the process of forming the diction. Of course, the expression comes in the form of slang which is only appropriate if the speech situation is informal or casual.

\section{References}

Alwi, Hasan et al. 2004. Standard indonesian grammar. Jakarta: Gramedia.

DeAndrea, D. C., Shaw, A. S., \& Levine, T. R. (2010). Online language: The role of culture in selfexpression and self-construal on Facebook. Journal of Language and Social Psychology, 29(4), 425-442. https://doi.org/10.1177/0261927X10377989

Goel, A., Rugaber, S., \& Vattam, S. (2009). Structure, behavior, and function of complex systems: The structure, behavior, and function modeling language. Artificial Intelligence for Engineering Design, Analysis and Manufacturing, 23(1), 23-35. doi:10.1017/S0890060409000080

Holmes, Janet. An introduction to sociolinguistics. New York: Longman Publishing.

Indrasari, E., Achsani, F., \& Lestari, B. (2019). Netizen sarcasm in comments on the Instagram account 'Lambe Turah'. Semantics, 8(1), 37-49.

James C. Lester, Stuart G. Towns, Patrick J. Fitzgerald. (1998). Achieving affective impact: Visual emotive communication in lifelike pedagogical agents. International Journal of Artificial Intelligence in Education (IJAIED), 10, pp.278-291.

Lorenz M. 1953. Language as expressive behavior. Ama Arch NeurPsych, 70(3), 277-285. doi:10.1001/archneurpsyc.1953.02320330002001

Mualafina, Rawinda Fitrotul. (2017). Use of asterisk (*) in social media. eprints.upgris.ac.id. November 9,2020 , at 2:31 p.m.

Roberson, D., Damjanovic, L., \& Kikutani, M. (2010). Show and tell: The role of language in categorizing facial expression of emotion. Emotion Review, 2(3), 255-260. https://doi.org/10.1177/1754073910361979

Sari, Lisa Purnama. (2016). Language variety alay in the social network (The variety of alay language used in social networks). Journal of Language, Literature, and Its Teaching, 6(2), 210 - 220.

Wijayanti, A., \& Shalima, I. (2018). Homonimi dan polisemi pada unggahan jenaka di Instagram. Transformatika, 2 (2), 88-101. 